\title{
PENGARUH MODEL PEMBELAJARAN DISCOVERY LEARNING BERBASIS LINGKUNGAN SEKOLAH TERHADAP HASIL BELAJAR SISWA PADA MATERI KEANEKARAGAMAN HAYATI
}

\author{
Syifa Saputra ${ }^{1}$ \\ ${ }^{1}$ Dosen Program Studi Pendidikan Biologi Universitas Almuslim-Bireuen \\ Email : syifa.mpbiounsyiah@gmail.com
}

Diterima 25 Juli 2016/Disetujui 30 Oktober 2016

\begin{abstract}
ABSTRAK
Penelitian ini bertujuan untuk melihat pengaruh model pembelajaran discovery learning berbasis lingkungan sekolah terhadap hasil belajar siswa pada materi keanekaragaman hayati. Metode Penelitian yang digunakan adalah pendekatan kuantitatif. Sedangkan jenis penelitian yang digunakan adalah penelitian eksperimen dengan menggunakan rancangan penelitian Pretest-Posttest Control Group Design. Berdasarkan hasil uji hipotesis diperoleh nilai t-hitung 5,58 dengan signifikasi 0,00 lebih rendah dari 0,05. Hal ini dapat disimpulkan Ha diterima dan $\mathrm{H}_{0}$ ditolak. Berarti terdapat pengaruh model pembelajaran Discovery Learning berbasis lingkungan sekolah terhadap peningkatan hasil belajar siswa.
\end{abstract}

Kata kunci $\quad$ : Discovery Learning, Lingkungan Sekolah dan Keanekaragaman Hayati.

\section{PENDAHULUAN}

\section{Latar Belakang}

Pembelajaran dalam biologi dapat didefinisikan sebagai proses pengkajian ilmu secara sistematis dan lebih komplek dengan memberi wawasan tentang ilmu alam yang berkaitan dengan makhluk hidup dan aspek-aspek yang mempengaruhinya. Belajar selalu berkenaan dengan perubahan-perubahan pada diri orang yang belajar, yang mengarah pada tujuan tertentu. Dimyati dan Mudjiono (2009) mengatakan bahwa belajar merupakan hasil suatu proses belajar mengajar dengan membawa suatu perubahan dan pembentukan tingkah laku seseorang. Gagne dalam Suprijono (2010), mengatakan bahwa belajar adalah perubahan kemampuan yang dicapai seseorang melalui proses dan aktifitas belajar, bukan diperoleh langsung dari proses pertumbuhan secara alamiah. Sedangkan hasil belajar adalah hasil yang dicapai dalam bentuk skor atau angka-angka setelah diberikan tes belajar pada setiap akhir pembelajaran. Menurut Fauziah (2004), hasil belajar adalah hasil yang diperoleh siswa setelah mengikuti suatu materi tertentu, dari mata pelajaran yang berupa data kualitatif maupun kuantitatif.

Untuk melihat hasil belajar perlu dilakukan suatu penilaian terhadap siswa yang bertujuan untuk mengetahui apakah siswa telah menguasai materi atau belum. Dalam pelaksanaan proses belajar mengajar, guru dituntut untuk lebih kreatif, inovatif, efektif dan menyenangkan, agar siswa menjadi aktif sehingga dapat memenuhi kompetensi yang diharapkan, sehingga menjadi faktor utama yang mempengaruhi keberhasilan dalam belajar.

Salah satu model pembelajaran yang dianggap dapat meningkatkan hasil belajar siswa dan berperan aktif dalam proses belajar mengajar adalah model Discovery Learning. Dengan menggunakan model Discovery Learning diharapkan dapat meningkatkan hasil belajar siswa dan keaktifan siswa. Dalam kegiatan belajar mengajar pendekatan ini mempunyai peranan sangat penting untuk menentukan keberhasilan proses belajar dan mengajar. Hal yang memacu peneliti untuk menggunakan model ini berdasarkan hasil penelitian Mubarok dan Sulistyo (2014) "bahwa hasil belajar siswa yang menggunakan model pembelajaran Discovery Learning lebih tinggi dari pada hasil belajar siswa yang menggunakan model pembelajaran langsung, dengan nilai rata-rata 80,176 pada model pembelajaran Discovery Learning dan 76,083 pada model pembelajaran langsung. Sehingga dapat disimpulkan bahwa model pembelajaran Discovery Learning berpengaruh positif terhadap hasil belajar siswa.

Adapun tujuan yang ingin dicapai dalam penelitian ini adalah untuk mengetahui adanya pengaruh model pembelajaran Discovery Learning berbasis lingkungan sekolah terhadap hasil belajar siswa pada materi keanekaragaman hayati kelas $\mathrm{X}$ SMA Negeri 2 Bireuen. 


\section{METODE PENELITIAN}

Metode Penelitian yang digunakan adalah pendekatan kuantitatif. Sedangkan jenis penelitian yang digunakan adalah penelitian eksperimen. Menggunakan rancangan penelitian dengan teknik Pretest-Posttest Control Group Design. Penelitian ini dilaksanakan di SMA Negeri 2 Bireuen dengan pengambilan data pada semester genap tahun ajaran 2015/2016.

\section{Populasi dan Sampel}

Populasi dalam penelitian ini adalah seluruh siswa kelas $\mathrm{X}$ yang berjumlah 177 siswa yang terdiri dari 5 kelas paralel. Untuk mengetahui seluruh kemampuan awal siswa diawali dengan melakukan pre-test terhadap ke-5 kelas tersebut. Siswa yang dijadikan sampel penelitian berjumlah 60 orang siswa. Pengambilan sampel dilakukan dengan teknik claster random sampling terhadap 60 siswa yang mempunyai nilai pre-test sama atau tidak beda nyata yang terdirì dari dua kelas yaitu X Mia 5 sebagai kelas eksperimen dan X Mia 6 sebagai kelas kontrol.

\section{Teknik Pengumpulan Data}

Teknik pengumpulan data adalah pre-test dan post-test dengan menggunakan instrument test dalam bentuk soal pilihan ganda sebanyak 20 soal.

\section{Teknik Analisis Data}

Sebelum instrument dijadikan alat pengumpul data, terlebih dahulu instrument diuji cobakan pada siswa kelas XI yang sudah pernah belajar tentang materi keanekaragaman hayati. Soal yang diuji cobakan berjumlah 40 soal dalam bentuk pilihan ganda, kemudian dianalisis dengan langkah sebagai berikut:

\section{a. Uji Validitas}

Dimana :

$$
\text { rpbis }=\frac{M p-M t}{s t} \sqrt{\frac{p}{q}}
$$

(Arikunto, 2006)

- $r_{p b i s}$ : koefisien korelasi biserial

- $M p \quad$ : Rata skor subjek yang menjawab benar bagi item yang validitasnya

- Mt : Rata skor total

- st : Standar deviasi dari skor total

- $p \quad$ : Proporsi siswa yang menjawab benar

- $q$ : proporsi siswa yang menjawab salah Jika instrument valid, maka dapat dilihat kriteria indeks korelasinya ( $r$ ) (lihat table 1).

Tabel 1 Kriteria Validitas Butir Tes

\begin{tabular}{ll}
\hline \multicolumn{1}{c}{ Validitas } & \multicolumn{1}{c}{ Kategori } \\
\hline $0,800-100$ & Sangat tinggi (valid) \\
$0,600-0,799$ & Tinggi (Valid) \\
$0,400-0,599$ & Cukup (Valid) \\
$0,200-0,399$ & Rendah (Valid) \\
$0,000-0,199$ & Sangat Rendah (Tidak Valid) \\
\hline
\end{tabular}

\section{b. Tingkat kesukaran}

Tingkat kesukaran didefinisikan sebagai proporsi siswa peserta tes yang menjawab benar.

Rumus : $\quad p=\frac{B}{j s}$ (Arikunto, 2009)

Dimana :

$p$ : Tingkat kesukaran butir soal

$B$ : Banyaknya siswa yang menjawab soal

$J_{S}:$ Jumlah seluruh peserta tes

\section{c. Daya Beda}

Daya beda adalah kemampuan butir soal yang membedakan siswa yang tingkat kemampuan tinggi dan rendah. Angka yang menunjukkan besarnya daya pembeda disebut indeks deskreminasi (D), untuk menentukan daya beda digunakan rumus sebagai berikut :

Dimana:

$$
D=\frac{\sum A}{n A}-\frac{\sum B}{n B} \quad \text { (Arikunto, 2009) }
$$

D : Indeks daya beda butir soal

$\sum A$ : Jumlah peserta tes yang menjawab

benar pada kelompok atas

$\sum B \quad$ : Jumlah peserta tes yang menjawab benar pada kelompokk bawah

$n A \quad:$ Jumlah peserta tes kelompok atas

$n B \quad$ : Jumlah peserta tes kelompok bawah

\section{d. Reabilitas}

Reabilitas adalah uji untuk memastikan apakah kusioner penelitian digunakan untuk mengumpulkan data variable penelitian.

Dimana:

$$
r_{1 l}=1-\frac{V d}{V t} \quad \text { (Arikunto, 2010) }
$$

$r_{11} \quad$ : reabilitas instrument

Vd : varians (varian difference)

$V t \quad$ : varian total atau varian skor total

Apabila harga $r_{l l}$ dikonsultasikan dengan $\mathrm{r}$ tabel produk moment dapat diketahui bahwa lebih kecil dari harga $r$ tabel yang ada. Dengan demikian dapat disimpulkan bahwa instrument tersebut tidak reliabel.

Dalam merumuskan reabilitas harus mencari varian terlebih dahulu dengan rumus:

$$
V=\frac{\sum x^{2} \frac{\left(\sum x^{2}\right)}{N}}{N} \quad \text { (Arikunto, 2010) }
$$

\section{e. Analisis data ketuntasan hasil belajar}

Untuk menghindari kesalahan dalam menginterpretasikan perolehan gain masing-masing siswa, maka dilakukan normalitas gain dengan menggunakan rumus sebagai berikut:

$$
N-g=\frac{\text { skorposttest }- \text { pretest }}{\text { skormaksimal -skor pretest }} \times 100
$$

Dimana:

$$
\begin{array}{ll}
\text { N-Gain }>70 & \text { kategori tinggi } \\
30 \leq N-G a i n \leq 70 & \text { kategori sedang } \\
\text { N-gain }<30 & \text { kategori rendah }
\end{array}
$$

Skor rata-rata gain ternormalisasi N-Gain antara kelompok eksperimen dan kelompok kontrol digunakan sebagai data untuk membandingkan 
kemampuan penguasaan konsep. Pengujian perbedaan kedua rata-rata $\mathrm{N}$-Gain antara eksperimen dan kontrol harus berdistribusi normal dan memiliki varian yang sama (homogen).

\section{f. Uji Prasyarat}

1) Uji Normalitas

Untuk mengetahui data yang diperoleh dari populasi yang berdistribusi normal atau tidak. Perhitungannya dengan menggunakan rumus:

$$
x^{2}=\sum_{i-1}^{k}=\frac{(f o-f e)^{2}}{f e}
$$

(Sudjana, 2006)

Keterangan:

$x^{2} \quad$ : Chi kuadrat

$i \quad$ : banyaknya kelas

fe : Frekuensi yang digunakan pada tes awal

fo : Frekuensi yang diharapkan pada tes akhir

2) Uji Homogenitas

Uji homogenitas adalah uji kesamaan dua variabel, yaitu dengan membandingkan kedua variannya. Untuk menguji kesamaan dua varian digunakan rumus:

$$
F=\frac{\text { Varian terbesar }}{\text { Varian terkecil }} \quad \text { (Sugiono, 2011) }
$$

Menurut Sugiono (2011) adalah :

a. Apabila harga $\mathrm{F}_{\text {hitung }} \leq \mathrm{F}_{\text {tabel }}$ untuk kesalahan $5 \%$ dan $1 \%(\mathrm{Fh}<\mathrm{Ft}(5 \%)<\mathrm{Ft}(1 \%)$. Maka data yang akan dianalisis homogen.

b. Jika $F_{\text {hitung }} \geq F_{\text {tabel }}$, maka varians tidak homogen.

3) Uji Hipotesis

Di dalam pengujian analisis ini, digunakan rumus Uji-

$$
\text { uji } t=\frac{x_{1}-x_{2}}{\sqrt[s]{\frac{1}{n_{1}}+\frac{1}{n_{2}}}} \quad \text { (Sudjana, 2006) }
$$

Keterangan:

$t$ : Harga t yang dicari

$x_{1}$ : rata-rata nilai tes kelas kontrol

$x_{2}$ : rata-rata nilai tes kelas eksperimen

$S$ : simpangan baku

$n_{1}$ : Jumlah siswa kelas eksperimen

$n_{2}$ : Jumlah siswa kontrol

Untuk diterima atau ditolaknya hipotesis digunakan taraf signifikan dengan kriteria sebagai berikut:

a. Apabila $t_{\text {hitung }}>t_{\text {tabel }}$ maka Ha diterima

b. Apabila $t_{\text {hitung }}<t_{\text {tabel }}$ maka Ho ditolak,

\section{HASIL DAN PEMBAHASAN}

\section{Deskripsi Nilai Pretest Kelas Eksperimen dan Kontrol}

Berdasarkan penelitian yang telah dilaksanakan di dua kelas, yaitu kelas X MIA 6 yang terdiri dari 30 siswa sebagai kelas eksperimen, dan kelas X MIA 5 yang terdiri dari 30 siswa sebagai kelas kontrol. Analisis data pretest yang telah dilakukan pada siswa kelas X MIA 6 sebagai kelas eksperimen dan kelas X MIA 5 sebagai kelas kontrol. Kelas eksperimen memperoleh nilai minimum 16.00 dan nilai maksimumnya 56.00. Pada kelas kontrol memperoleh nilai minimum 28,00 sedangkan nilai maksimum 60,00. Untuk Standar deviasi kelas eksperimen 9,25 dan pada kelas kontrol 8,53, nilai rata-rata pretes untuk kelas eksperimen adalah 38,73 dan nilai ratarata kelas kontrol 48,13. Dapat dilihat bahwa pada tes kemampuan awal nilai kelas kontrol lebih tinggi dari kelas eksperimen, meskipun tidak berbeda jauh (lihat tabel 2).

Tabel 2 Deskripsi Nilai Pretest pada Kelas Kontrol dan Eksperimen

\begin{tabular}{cccccc}
\hline Kelas & $\mathrm{N}$ & $\begin{array}{c}\text { Nilai } \\
\text { Min }\end{array}$ & $\begin{array}{c}\text { Nilai } \\
\text { Maks }\end{array}$ & $\begin{array}{c}\text { Rata- } \\
\text { rata }\end{array}$ & $\begin{array}{c}\text { Standar } \\
\text { Deviasi }\end{array}$ \\
\hline Eksperimen & 30 & 16,00 & 56,00 & 38,73 & 9,25 \\
Kontrol & 30 & 28,00 & 60,00 & 48,13 & 8,53 \\
\hline
\end{tabular}

Sumber: Hasil Ouput SPSS yang diolah, 2016

\section{Deskripsi Nilai Posttest Kelas Eksperimen dan Kontrol}

Analisis data postest yang telah dilakukan, diperoleh bahwa nilai minimum pada kelas eksperimen 76,00 dan nilai maksimum 92,00. Pada kelas kontrol nilai minimum 76,00 dan nilai maksimum 88,00. Rata-rata posttest pada kelas eksperimen adalah 83,46 dengan standar deviasi 5,72, sedangkan nilai rata-rata posttest untuk kelas kontrol lebih rendah dibandingkan dengan kelas eksperimen yaitu 79,45 dengan standar deviasi 4,42. Hal ini menunjukkan bahwa pada kelas eksperimen adanya pengaruh model pembelajaran Discovery Learning berbasis lingkungan sekolah terhadap peningkatan hasil belajar siswa (lihat tabel 3).

Tabel 3 Hasil Uji Nilai Posttest pada Kelas Kontrol dan Eksperimen

\begin{tabular}{cccccc}
\hline Kelas & N & $\begin{array}{c}\text { Nilai } \\
\text { Min }\end{array}$ & $\begin{array}{c}\text { Nilai } \\
\text { Maks }\end{array}$ & $\begin{array}{c}\text { Rata- } \\
\text { rata }\end{array}$ & $\begin{array}{c}\text { Standar } \\
\text { Deviasi }\end{array}$ \\
\hline $\begin{array}{c}\text { Eksperimen } \\
\text { Kontrol }\end{array}$ & 30 & 76,00 & 92,00 & 83,46 & 5,72 \\
76,00 & 88,00 & 79,45 & 4,42 \\
\hline
\end{tabular}

Sumber : Hasil Ouput SPSS yang diolah, 2016

\section{Deskripsi Nilai N-Gain Kelas Eksperimen dan Kontrol}

Analisis data N-Gain yang telah dilakukan pada kelas eksperimen mempunyai nilai minimum 28.00 dan nilai maksimumnya 64,00. Sedangkan kelas kontrol memperoleh nilai minimum 16,00 dan nilai maksimum 56,00. Kemudian pada kelas eksperimen rata-rata $\mathrm{N}$-Gain yaitu 44,73 dengan standar deviasi 8,24 . Kelas kontrol rata-rata $\mathrm{N}$-Gain yaitu 31,33 dengan standar deviasi 10,24. Oleh karena itu, terdapat peningkatan hasil belajar siswa (lihat tabel 4).

\section{Deskripsi Nilai Normalitas Data}

Analisis uji normalitas menggunakan uji Kolmogorov-Smirnov, menunjukkan bahwa data $\mathrm{N}$ Gain kelas eksperimen berdistribusi normal. Hal 
Tabel 4 Hasil Uji Nilai N-Gain pada Kelas Kontrol dan Eksperimen

\begin{tabular}{cccccc}
\hline Kelas & $\mathrm{N}$ & $\begin{array}{c}\text { Nilai } \\
\text { Min }\end{array}$ & $\begin{array}{c}\text { Nilai } \\
\text { Maks }\end{array}$ & Mean & $\begin{array}{c}\text { Standar } \\
\text { Deviasi }\end{array}$ \\
\hline Eksperimen & 30 & 28,00 & 64,00 & 44,73 & 8,24 \\
Kontrol & 30 & 16,00 & 56,00 & 31,33 & 10,24 \\
\hline
\end{tabular}

Sumber: Hasil Ouput SPSS yang diolah, 2016

tersebut ditunjukkan dengan nilai $\mathrm{P}(0,16)$ sama dengan nilai $\alpha(0,05)$. Hasil uji kolmogorov-Smirnov untuk data $\mathrm{N}$-Gain kelas eksperimen menunjukkan bahwa skor berdistribusi normal (lihat tabel 5).

Tabel 5 Hasil Uji Normalitas Data Kelas Kontrol dan Eksperimen

\begin{tabular}{cccccc}
\hline Kelas & $\begin{array}{c}\text { Sam } \\
\text { pel }\end{array}$ & Statistik & $\begin{array}{c}\text { Sign } \\
(\mathrm{P})\end{array}$ & $\alpha$ & Simpulan \\
\hline Eksperimen & 30 & 0,134 & 0,16 & 0,05 & Normal \\
Kontrol & 30 & 0,141 & 0,13 & 0,05 & Normal \\
\hline
\end{tabular}

Sumber : Hasil Ouput SPSS yang diolah, 2016

Ket:

Jika $\mathrm{P}$ (sig) $>\alpha$ terima $\mathrm{H}_{0}$ (berdistribusi normal)

Jika $\mathrm{P}(\mathrm{sig})<\alpha$ terima $\mathrm{H}_{0}$ (tidak berdistribusi normal)

\section{Deskripsi Nilai Homogenitas Data}

Uji homogenitas menggunakan uji KolmogorovSmirnov yang telah dilakukan menunjukkan bahwa data N-Gain kelas kontrol memiliki standar deviasi yanghomogen. Hal tersebut ditunjukkan dengan nilai P $(0,25)$ sama dengan nilai $\alpha(0,05)$. Hasil uji homogenitas untuk kelas eksperimen menunjukkan bahwa memiliki standar deviasi yang homogen (lihat tabel 6).

Tabel 6 Hasil Homegenitas Data Kelas Kontrol dan Eksperimen

\begin{tabular}{cccccc}
\hline Kelas & $\begin{array}{c}\text { Sampe } \\
1\end{array}$ & $\begin{array}{c}\text { Statistik } \\
\text { levene }\end{array}$ & $\begin{array}{c}\text { Sign } \\
(\mathrm{P})\end{array}$ & $\alpha$ & $\begin{array}{c}\text { Simp } \\
\text { ulan }\end{array}$ \\
\hline $\begin{array}{c}\text { Eksperim } \\
\text { en }\end{array}$ & 30 & 1,34 & 0,25 & 0,05 & $\begin{array}{c}\text { homo } \\
\text { gen }\end{array}$ \\
Kontrol & 30 & & & & \begin{tabular}{c} 
\\
\hline
\end{tabular}
\end{tabular}

Sumber : Hasil Ouput SPSS yang diolah, 2016

Ket:

Jika $\mathrm{P}($ sig $)>\alpha$ terima $\mathrm{H}_{0}$ (homogen)

Jika $\mathrm{P}($ sig $)<\alpha$ terima $\mathrm{H}_{0}$ (tidak homegen)

\section{Hasil Uji Hipotesis (Uji -t)}

Uji independent samples test yang telah dilakukan menunjukkan bahwa nilai Uji-t adalah 5,58 dengan signifikasi $\mathrm{P}(0,00) \leq \alpha(0,05)$ berarti Ha di terima dan $\mathrm{H}_{0}$ di tolak. Hipotesis alternatif menunjukkan bahwa adanya pengaruh model pembelajaran Discovery Learning berbasis lingkungan sekolah terhadap peningkatan hasil belajar siswa pada materi Keanekaragaman Hayati di SMA Negeri 2 Bireuen (lihat tabel 7).
Tabel 7 Hasil Analisis Uji Hipotesis

\begin{tabular}{ccccc} 
Uji & Nilai-t & $\begin{array}{c}\text { Signifikansi } \\
(\mathrm{P})\end{array}$ & $\alpha$ & Simpulan \\
\hline Uji-t & 5,58 & 0,00 & 0.05 & $\begin{array}{c}\text { Terima } \\
\text { Ha }\end{array}$ \\
\hline
\end{tabular}

Sumber : Ouput SPSS yang diolah, 2016

Ket:

Jika $\mathrm{P}$ ( sig) $>\alpha$ terima $\mathrm{H}_{0}$ (tidak berpengaruh)

Jika $\mathrm{P}($ sig $)<\alpha$ terima $\mathrm{H}_{0}$ (berpengaruh)

\section{Pembahasan}

Berdasarkan hasil pengolahan data yang telah di lakukan nilai rata-rata kelas eksperimen pada saat Pretest adalah 38,00 sedangkan nilai rata-rata pada kelas kontrol 48,13. Terdapat perbedaan nilai yang sangat jauh antara kelas eksperimen dan kelas kontrol, karena pada saat mengisi soal pretest siswa pada kelas eksperimen kurang serius dan kesan seperti bermain main. Berbeda dengan siswa pada kelas kontrol mereka lebih teliti dalam membaca soal sehingga ratarata nilai pretestnya lebih tinggi. Pada Posttest kelas eksperimen nilai rata-rata yang diperoleh 83,46 sedangkan pada kelaskontrol mendapatkan nilai 79,45. Hal ini membuktikan bahwa nilai posttest pada kelas eksperimen jauh lebih meningkat dibandingkan dengan nilai posttest kelas kontrol.

Nilai N-gain pada kelas eksperimen memperoleh nilai 44,73 dan kelas kontrol memperoleh nilai 31,33 membuktikan siswa di kelas eksperimen mengalami hasil belajar lebih baik dibandingkan dengan kelas kontrol dikarenakan siswa kelas eksperimen menggunakan model pembelajaran Discovery Learning berbasis lingkungan sekolah sedangkan kelas kontrol hanya menggunakan model konvensional. Untuk membuktikan hal tersebut maka perlu dilakukan analisis data menggunakan uji statistik untuk mengetahui adanya pengaruh model pembelajaran Discovery Learning berbasis lingkungan sekolah terhadap peningkatan hasil belajar siswa. Hal tersebut dapat diketahui dengan menggunakan uji-t yang juga digunakan sebagai uji hipotesis hasil belajar. Namun sebelum melakukan uji hipotesis maka terlebih dahulu dilakukan uji normalitas dan uji homogenitas. Berdasarkan hasil uji normalitas menggunakan uji Kolmogorov-Smirnov dengan program SPSS Versi 16 dapat di peroleh nilai signifikasi pada kelas eksperimen 0,13 lebih tinggi dari 0,05 sedangkan pada kelas kontrol nilai signifikasi 0,16 lebih tinggi dari pada 0,05. Berdasarkan hasil tersebut dapat disimpulkan bahwa kedua kelas tersebut berdistribusi normal, hasil uji homogenitas yang telah dilakukan menggunakan statistik Levene Test dengan menggunakan program SPSS Versi 16 dapat diperoleh nilai signifikasi 0,25 lebih tinggi dari pada 0,05 dengan demikian data tersebut termasuk dalam katagori homogen.

Berdasarkan hasil uji hipotesis diperoleh nilai t-hitung 5,58 dengan signifikasi 0,00 lebih rendah dari 
0,05. Hal ini dapat disimpulkan Ha diterima dan $\mathrm{H}_{0}$ ditolak. Berarti terdapat pengaruh model pembelajaran Discovery Learning berbasis lingkungan sekolah terhadap peningkatan hasil belajar siswa sehingga siswa dapat aktif belajar secara mandiri, mencari, memecahkan masalah dan menyampaikan ide serta gagasan baru melalui penemuan yang ditemukannya, sehingga pemahaman dan hasil belajar siswa menjadi lebih baik, pada kelas kontrol siswa yang diajarkan model konvensional siswa tidak berani bertanya dan siswa menjadi pendengar saja, ada sebagian siswa hanya mengharap bantuan dari temannya, pada kelas kontrol siswa kurang aktif dalam belajar. Hal ini sesuai dengan pendapat Syarif (2015), model Discovery Learning adalah model pembelajaran yang membuat siswa aktif untuk menemukan beberapa konsep dan prinsip yang sedang dipelajari. Hal ini sejalan dengan pendapat Ruswandi dan Badrudin (2008), pemanfaatan lingkungan sebagai media pembelajaran akan menjadikan proses belajar lebih bermakna. Suatu yang dipelajari oleh siswa lebih nyata, lebih faktual dan kebenarannya dapat dipertanggungjawabkan.

Keberhasilan model pembelajaran Discovery Learning berbasis lingkungan sekolah terhadap peningkatan hasil belajar siswa menurut Istarani (2012) adalah mampu memberikan kesempatan pada siswa untuk berkembang dan maju sesuai dengan kemampuannya masing-masing sehingga siswa dapat memahami dan menghayati aspek-aspek kehidupan yang ada pada lingkungan sekitar, berbeda dengan model konvensional yang hanya terpaku pada metode ceramah dan siswa kurang aktif dalam belajar, penguasaan materi kurang tepat, media yang terbatas, pada akhirnya menyebabkan hasil belajar rendah.

Model pembelajaran Discovery Learning sangat banyak memberikan perubahan kepada siswa, sesuai dengan penelitian yang telah di lakukan sebelumnya oleh Mubarok dan Sulistyo (2014) bahwa penerapan model pembelajaran Discovery Learning memiliki pengaruh terhadap hasil belajar siswa dan memiliki respon baik terhadap penerapan model pembelajaran tersebut. Penelitian selanjutnya dilakukan oleh Putrayasa, dkk, (2014) menunjukkan bahwa pengaruh model pembelajaran Discovery Learning berpengaruh terhadap hasil belajar siswa. Sehingga pada akhirnya akan mewujudkan kondisi siswa yang aktif dalam kegiatan belajar, meningkatkan aktivitas guru selama pembelajaran, juga bisa melatih keterampilan guru agar mengubah dari centered learning menjadi student centered, dan pemanfaatan lingkungan sekolah sebagai media pembelajaran dalam proses pembelajaran dapat menimbulkan reaksi siswa terhadap penjelasan guru, memungkinkan siswa untuk menyentuh objek kajian pelajaran, mengkonkretkan konsep yang abstrak, serta dapat mendeskripsikan masalah sehingga dapat di katakan bahwa pembelajaran Discovery Learning terhadap peningkatan hasil belajar siswa lebih baik dari pada model yang diterapkan secara konvensional.

\section{SIMPULAN}

Berdasarkan hasil dan pembahasan dapat disimpulkan bahwa adanya pengaruh model pembelajaran Discovery Learning berbasis lingkungan sekolah terhadap peningkatan hasil belajar siswa pada materi Keanekaragaman Hayati di SMA Negeri 2 Bireuen.

\section{DAFTAR PUSTAKA}

Arikunto, S. 2006. Prosedur Penelitian. Jakarta : PT Asdi Mahasatya.

Arikunto, S. 2009. Dasar-dasar evaluasi Pendidikan. Jakarta : Bumi Aksara

Arikunto, S. 2010. Prosedur Penelitian. Jakarta : PT Asdi Mahasatya.

Dimyati dan Mudjiono, 2009. Belajar dan Pembelajaraan. Jakarta : rineka Cipta.

Fauziah, 2004. Jurnal Serambi PTK . Melalui Permainan Gambar Dapat Meningkatkan Hasil Dan Aktivitas Belajar Bahasa Inggris Materi Things Around Us Siswa Kelas VII SMP Negeri 1 Darul Kamal Tahun Pelajaran 2013-2014. Volume 1. 6-12.

Istarani, 2012. Kumpulan 40 Metode Pembelajaran. Medan: Media Persada.

Mubarok, C., \& Sulistyo. E. 2014. Jurnal Pendidikan Teknik Elektro.Penerapan Model Pembelajaran Discovery Learning Terhadap Hasil Belajar Siswa Kelas X TAV Pada Standar Kompetensi Melakukan Instalasi Sound System Di SMK Negeri 2 Surabaya. Volume 03. 215 - 221.

Putrayasa, dkk. 2014. Jurnal Mimbar PGSD Universitas Pendidikan Ganesha. Pengaruh Model Pembelajaran Discovery Learning dan Minat Belajar Terhadap Hasil Belajar Ipa Siswa. Volume 02. No, 01.

Ruswandi, U., \& Badrudin. 2008. Media Pembelajaran. Bandung: CV. Insan Mandiri.

Sudjana, N. 2006. Penilaian Hasil Proses Belajar Mengajar. Bandung: PT. Remaja Rosdakarya.

Sugiono. 2011. Metode Penelitian Pendidikan. Bandung: Alfabeta. 
ISSN: 2302-1705

JESBIO Vol. V No. 2, November 2016

Suprijono, A. 2010. Cooperative Learning.

Yogyakarta: Pustaka Belajar.

Syarif, M. 2015. Materi Pelatihan Guru Implementasi

Kurikulum 2013 tahun 2015. Kementrian

Pendidikan dan Kebudayaan: Badan

Pengembangan Sumber Daya Manusia dan

Kebudayaan dan Penjaminan Mutu

Pendidikan.Putrayasa, dkk, (2014). 